\title{
PRIVATE SECURITY PREPAREDNESS FOR DISASTERS CAUSED BY NATURAL AND ANTHROPOGENIC HAZARDS
}

\author{
Vladimir M. Cvetković ${ }^{*}$, Bojan Janković ${ }^{2}$ \\ ${ }^{1}$ Faculty of Security Studies, University of Belgrade, Gospodara Vucica 50, \\ 11040 Belgrade, Serbia; vmc@fb.bg.ac.rs \\ 2 University of Criminal Investigation and Police Studies, Belgrade, Serbia; \\ bojan.jankovic@kpu.edu.rs \\ Correspondence: vmc@fb.bg.ac.rs \\ Received: 10 April; Accepted: 20 May; Published: 10 September
}

\begin{abstract}
The subject of the research is to examine the private security preparedness for disasters caused by natural and anthropogenic hazards. In addition, the relationship between preparedness levels and various demographic and socio-economic factors is examined. The survey was anonymous with 4-point Likert scale questions (1- I absolutely disagree; 4- I absolutely agree). It was conducted at the University of Criminal Investigation and Police Studies in Belgrade, during the initial course for obtaining a private security license and the course for combating domestic violence were attended by members of the police from all over Serbia. Data for the study were collected from a total of 178 members of private security. The research was conducted from April to June 2019. Within the first part of the questionnaire, there were questions concerning demographic and socio-economic characteristics of the respondents (gender, age, education, marital status, working experience, served military status), while the second part contained questions about the $\mathrm{p}$ the private security preparedness for disasters caused by natural and anthropogenic hazards (e.g perception of the degree of responsibility due to the type of work performed in case of natural and anthropogenic disasters, perception of the level of preparedness of a private insurance company, knowledge of safety procedures for disaster response, evaluation of the response efficiency of first responders, etc.). The results of the multivariate regressions of preparedness subscale showed that variables (e.g., gender, age, education, marital status) were not significantly affected by preparedness.
\end{abstract}

Keywords: security, disaster, preparedness, private security, natural and anthropogenic hazards, Serbia. 


\section{Introduction}

The traditional view that only the police are responsible for security, largely leaves in the sense that private security has a more important place (Janković, 2020). Although traditionally responsible for the realization of public safety, the police are not able to make it happen without adequate planning, organized and sustained cooperation with other state and local authorities, and increasingly the subjects of private security (Lončar, Radivojević, Radošević, \& Mirković, 2019b). This is shown by the data on the increase in the volume of work entrusted to the private security industry, as well as the increase in the number of employees in it (Janković, Cvetković, \& Ivanov, 2019). Thus, estimates of the number of employees in the industry in the Republic of Serbia, ranges from 30,000 (Davidović \& Kešetović, 2017), over $40-50,000$ (Nalla \& Gurinskaya, 2017), according to the latest data, the number goes up to 60,000 employees (Milošević, 2018).

Members of private security perform a wide range of tasks. They perform various tasks that include patrol and surveillance duties, crime prevention, information security, risk management, improving preparedness for disasters (Cobbina, Nalla, \& Bender, 2013; Nalla \& Cobbina, 2017). Besides of securing property and persons in normal circumstances, a private security plays an important role and tasks in risk prevention (Davidović \& Kešetović, 2017). The destructiveness and unpredictability of various natural and anthropogenic disasters imposes the need for short-term and long-term planning in order to prevent or mitigate the consequences of such events. Integrated disaster risk management, which should include private security, implies taking various structural and non-structural measures to mitigate the consequences of future disasters. Although some studies have indicated that the police are generally the first civil service to respond to natural disasters (Milojković et al., 2015), it is also necessary to improve the preparedness of all other first responders in order to provide an appropriate response in the event of a disaster. Such activities relate to the education of members, equipping and technical improvement of services, continuous implementation of training and coaching and continuous improvement of knowledge and skills in terms of providing answers at all strategic, tactical and operational levels. Cvetković, Nikolić, Nenadić, Ocal, and Zečević (2020) in their research on the catastrophe caused by COVID-19, they point out that all cities and towns in Serbia need to have disaster plans that are tailored to specific scenarios and locations, not preconceived generalized plans, communications need to be standardized and supported and triage needs to be thought through more clearly. Also, they highlited that airport plane crashes, stadium catastrophes, and remote mass transit accidents are all very diferent from those caused by deadly infectious microorganisms such as COVID-19 and require dierent responses.

\section{Literary review}

Very few studies directly investigate the role of private security in emergencies (Lončar et al., 2019b). Thus, Lončar et al. (2019b) analyze the legal provisions related to the role of private security in the Republic of Serbia and the cooperation of private security with the police. The authors came to the conclusion that private security, if we exclude the undertaking of certain measures within the facility to be secured, is not included during disasters, ie it does not undertake protection and rescue activities on a wider scale. They came to the conclusion by analyzing the Law on Private Security ("Zakon o privatnom obezbeđenju," 2013) in which there are no provisions on the possibility of engaging private security in cases of declaring emergencies, while the Law on Disaster Risk Reduction and Emergency Manage- 
ment ("Zakon o smanjenju rizika od katastrofa i upravljanju vanrednim situacijama," 2018), private security is not explicitly mentioned at all as one of the strengths of the disaster risk reduction and emergency management system (Lončar, Radivojević, Radošević, \& Mirković, 2019a). During an emergency situation, private security has the task of implementing measures, but again within the protected facility, issued by the competent emergency headquarters (Lončar et al., 2019a). In contrast to Serbia, a good example is Romania, which has stipulated in its regulations that members of private security react as the first force in the event of fires and disasters (Nalla \& Gurinskaya, 2017).

Other research may indirectly reveal the role of private security in emergencies. We are of the opinion that the scope of engagement of members of private security in certain situations does not follow the research in this area. That a large number of private security personnel may be engaged during emergencies is indicated by the fact that during Hurricane Katrin in 2004, an estimated 20,000 private security personnel were deployed in New Orleans (Nalla \& Crichlow, 2017). This leads to the conclusion that in emergency situations there is a need for special and additional engagement of state bodies, but also various non-state entities, such as private security (Lončar et al., 2019a). Their engagement in emergencies should be set through an integrated approach to security, which means putting crime on a par with catastrophes, such as fires and health epidemics (Steden, 2007). Adopting this approach would lead to the drafting of a protocol setting standards for public / private cooperation during any emergency, and putting private umbrellas on private security teams, with all other entities (Steden, 2007). The role of members of the private security system may be particularly pronounced in emergencies caused by viral epidemics, when the infection of police officers may result in their absence from work, illness or death, when certain agencies may be involved in law enforcement (Brito, Luna, \& Sanberg, 2009). Pandemic planning is particularly complicated because it requires coordination with a wide range of other public and private agencies (Luna, Brito, \& Sanberg, 2007). At the beginning of such epidemics, the protection of hospitals and other critical infrastructure facilities is planned, which is carried out more often by the police, or as was the case in Serbia during COVID-19, health facilities were protected by the army (Djordjevic, 2020). Because police resources are limited, some police organizations hope that private security agencies could take over this function to some extent in order to reduce security threats (Luna et al., 2007). Private security agencies can play an important role in emergencies, if not identical to what the police have, then they can play an important complementary role through assistance to police organizations (Nalla \& Gurinskaya, 2017). Starting from this assumption that private security can play a significant role in disasters, the authors seek to establish whether they are members of private security prepared to justify the importance of their role, or how much they are prepared to engage in emergency situations.

\section{Methods}

The subject of the research is to examine the private security preparedness for disasters caused by natural and anthropogenic hazards. In addition, the relationship between preparedness levels and various demographic and socio-economic factors is examined. The survey was anonymous with 4-point Likert scale questions (1- I absolutely disagree; 4- I absolutely agree). 


\subsection{Questionnaire Design}

During February 2019, a pilot pre-test of the questionnaire was conducted in Belgrade with 15 members of private security) to test the comprehensibility and performance of the questionnaire developed for this research. All respondents voluntarily agreed to participate in the research. The research was conducted at the University of Criminal Investigation and Police Studies in Belgrade, during the initial course for obtaining a private security license and the course for combating domestic violence were attended by members of the police from all over Serbia. Data for the study were collected from a total of 178 members of private security. The research was conducted from April to June 2019. Within the first part of the questionnaire, there were questions concerning demographic and socio-economic characteristics of the respondents (gender, age, education, marital status, working experience, served military status), while the second part contained questions about the $\mathrm{p}$ the private security preparedness for disasters caused by natural and anthropogenic hazards (e.g perception of the degree of responsibility due to the type of work performed in case of natural and anthropogenic disasters, perception of the level of preparedness of a private insurance company, knowledge of safety procedures for disaster response, evaluation of the response efficiency of first responders etc.).

\subsection{Socio-Economic and Demographic Characteristics}

Out of 178 members of private security, $93.3 \%$ are men, while $6.7 \%$ are women. Given the ages of respondents, most of the private security members are 51-60 years old (30.3\%), and the fewest are over $60(6.7 \%)$. In relation to the level of education, the majority of respondents have a high school degree (87.6\%), and the minority have higher education (5.6\%). Regarding work experience, most respondents have over 15 years of work experience, and the majority of them did not serve military service (Table 1). The conducted research is part of a more extensive study on the relationship between the police and private security in the execution of tasks in the field of security.

Table 1. Demographic characteristics of private security respondents (n/percent)

\begin{tabular}{ccc}
\hline Variable & Category & Security $(\mathrm{n}=178)$ \\
\hline Gender & Male & $166(93.3)$ \\
& Female & $12(6.7)$ \\
Age (years) & $18-25$ & $16(9.0)$ \\
& $26-35$ & $14(7.9)$ \\
$36-45$ & $42(23.6)$ \\
$46-50$ & $26(14.6)$ \\
$51-60$ & $54(30.3)$ \\
& Over 60 & $12(6.7)$
\end{tabular}




\begin{tabular}{ccc} 
Education level & $\begin{array}{c}\text { Secondary } \\
\text { school }\end{array}$ & $156(87.6)$ \\
& High school & $12(6.7)$ \\
& University & $10(5.6)$ \\
Marital status & Married & $104(58.4)$ \\
& Single & $64(36)$ \\
Working experience & Divorced & $10(5.6)$ \\
& No & $20(11.2)$ \\
Served military service & $1-5$ years & $30(16.9)$ \\
& $6-10$ years & $16(9.0)$ \\
& $11-15$ years & $32(18)$ \\
& Over 15 years & $78(43.8)$ \\
& Yes & $144(80.9)$ \\
& No & $32(17.9)$ \\
\hline
\end{tabular}

\subsection{Analyses}

Socio-demographic characteristics of the respondents were explored using descriptive statistical analyzes. The analysis of variance (one-way ANOVA) and the regression analysis were used to examine the relation between the variables (gender, age, education, marital status, military service, previous experience) and the participants' attitudes. Analyses showed that the assumptions of normality, linearity, multicollinearity and homogeneity of variance had not been violated (Montgomery, Peck, \& Vining, 2012). The internal consistency of Likert scales for Preparedness Subscale (5 items) is good with a Cronbach's alpha of 0.81, for Knowledge Measurement Subscale (5) 0.82, Responsibility subscale (5) 0.84, and Response efficiency Subscale (5 items) 0.84. All tests were two-tailed, with a significance level of $\mathrm{p}<.05$. Statistical analysis was performed using SPSS Statistic 17.0 (IBM SPSS Statistics, New York, United States). This research conformed to the Helsinki Declaration, outlining the principles for socio-medical research involving human subjects and participants provided informed consent to participate in the study.

\section{Results and discussion}

Firstly, we tested the central hypothesis that gender, educational level, and age were predictive variables of private security preparedness for disasters caused by natural and anthropogenic hazards. Multivariate regression analysis was used to determine the extent to which four scores of the subscales (preparedness, knowledge, responsibility, response efficiency) were associated with fourth socio-economic variables: gender, age, marital status, education level. The results of the multivariate regressions of preparedness subscale showed that variables (e.g., gender, age, education, marital status) were not significantly affected by preparedness. This model $\left(R^{2}=0.026\right.$, Adj. $\left.R^{2}=-.007, F=.784, t=10.78, p>0.01\right)$ with all mentioned 
independent variables do not explain variance of preparation. Besides that, the results of the multivariate regressions of the knowledge subscale show that the most important predictor is the marital status $(\beta=.375)$, and it explains $37.5 \%$ of the variance in the knowledge subscale. The remaining variables (e.g., gender, age, education level) did not have significant effects on knowledge. This model $\left(R^{2}=.137\right.$, Adj. $\left.R^{2}=0.108, F=4.66, t=10.83, p=0.002\right)$, with all mentioned independent variables, explains $10.8 \%$ of the variance of knowledge subscale. The results of the multivariate regressions of responsibility subscale showed that variables (e.g., gender, age, education, marital status) were not significantly affected by preparedness. This model $\left(R^{2}=0.070\right.$, Adj. $\left.R^{2}=.038, F=2.21, t=6.04, \mathrm{p}>0.01\right)$ with all mentioned independent variables do not explain variance of responsibility subscale. Lastly, the results of the multivariate regressions of the response subscale show that the most important predictor is the marital status $(\beta=.213)$, and it explains $21.3 \%$ of the variance in the knowledge subscale. The remaining variables did not have significant effects on the response subscale. This model $\left(R^{2}=.053\right.$, Adj. $\left.R^{2}=0.021, F=1.63, t=12.28, p=0.170\right)$, with all mentioned independent variables, explains $10.8 \%$ of the variance of response subscale (Table 2 ).

Table 2. Results of a multivariate regression analysis concerning subscales (preparedness, knowledge, responsibility, and response) for private security preparedness for disasters caused by natural and anthropogenic hazards $(n=178)$

\begin{tabular}{|c|c|c|c|c|c|c|c|c|c|c|c|c|}
\hline \multirow{2}{*}{$\begin{array}{c}\text { Predictor } \\
\text { Variable }\end{array}$} & \multicolumn{3}{|c|}{$\begin{array}{l}\text { Preparedness } \\
\text { subscale }\end{array}$} & \multicolumn{3}{|c|}{$\begin{array}{c}\text { Knowledge } \\
\text { subscale }\end{array}$} & \multicolumn{3}{|c|}{$\begin{array}{l}\text { Responsibility } \\
\text { subscale }\end{array}$} & \multicolumn{3}{|c|}{$\begin{array}{l}\text { Response } \\
\text { efficiency }\end{array}$} \\
\hline & $B$ & $S E$ & $\beta$ & $B$ & $S E$ & $\beta$ & $B$ & $S E$ & $\beta$ & $B$ & $S E$ & $\beta$ \\
\hline Gender & .019 & .260 & .007 & .083 & .232 & .033 & .269 & .186 & .139 & .081 & .246 & .032 \\
\hline Age & -.124 & .226 & .226 & -.279 & .202 & .202 & .233 & .162 & .138 & .373 & .214 & .168 \\
\hline Education level & -.303 & .194 & .194 & -.193 & .173 & .173 & -.022 & .139 & -.015 & -.002 & .184 & -.001 \\
\hline Marital status & .047 & .129 & .129 & .375 & .115 & $.115^{*}$ & -.180 & .092 & -.184 & .274 & .122 & $.213^{*}$ \\
\hline Adjusted $R^{2}$ & & -.007 & & & 0.108 & & & 0.038 & & & 0.63 & \\
\hline
\end{tabular}

${ }^{\star} p \leq 0.05 ;{ }^{* *} p \leq 0.01 ; B$ : unstandardized $(B)$ coefficients; SE: std. error; $\beta$ : standardized $(\beta)$ coefficients. Note: males, young, high school, married have been coded as $0 ; 1$ has been assigned otherwise.

In further work, the influence of age, marital status and level of education on subscales as preparedness, knowledge, responsibility and response was examined. The obtained results show that respondents aged 51-60 years to a greater extent than respondents aged 36-45 years assess private security preparedness for disasters caused by natural and anthropogenic hazards $(p=.022)$. It can be assumed that the obtained research results primarily depend on the previous experience of the respondents with members of private security. Respondents aged 18-26 years are more likely to assess responsibility compared to respondents aged 4650 and 50-60 years $(p=.010)$. When it comes to marital status, it was found that married respondents marry knowledge to a greater extent than single respondents $(p=.002)$. Also, it was found that singles were more responsive than respondents who were married $(p=.009)$. In relation to the level of education, no statistically significant correlation was found with preparedness $(p=.109)$, knowledge $(p=.515)$, responsibility $(p=.560)$ (Table 3$)$. 
Table 3. ANOVA results between demographic variables and subscales as preparedness, knowledge, responsibility, and response $(n=178)$

\begin{tabular}{|c|c|c|c|c|}
\hline Variables & Categories & $\begin{array}{l}\text { Preparedness } \\
\text { X (sd) }\end{array}$ & $\begin{array}{c}\text { Knowledge } \\
\text { X (sd) }\end{array}$ & $\begin{array}{c}\text { Responsibility } \\
\text { X (sd) }\end{array}$ \\
\hline \multirow{7}{*}{$\stackrel{8}{<}$} & $18-26$ & $2.60(.91)$ & $2.25(1.12)$ & $1.62(.40)$ \\
\hline & $26-35$ & $2.30(.80)$ & $2.20(.92)$ & $1.25(.28)$ \\
\hline & $36-45$ & $3.01(.66)$ & $2.82(.51)$ & $1.28(.34)$ \\
\hline & $46-50$ & $2.70(.38)$ & $2.88(.30)$ & $1.15(.26)$ \\
\hline & $51-60$ & $2.55(.59)$ & $2.65(.60)$ & $1.35(.35)$ \\
\hline & +60 & $3.00(.23)$ & $2.80(.46)$ & $1.00(.000)$ \\
\hline & F/Sig. & $2.76\left(.022^{\star}\right)$ & $2.15(.065)$ & $3.19\left(.010^{\star}\right)$ \\
\hline \multirow{5}{*}{ 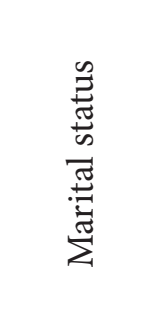 } & Single & $2.67(.64)$ & $2.47(.67)$ & $1.55(.71)$ \\
\hline & Widow/er & $3.00(.000)$ & $2.60(.000)$ & $1.00(.000)$ \\
\hline & Divorced & $2.55(.38)$ & $2.40(.45)$ & $1.16(.30)$ \\
\hline & Married & $2.74(.71)$ & $2.90(.57)$ & $1.25(.32)$ \\
\hline & F/Sig. & $.378(.769)$ & $5.20(.002)^{*}$ & $3.99(.009)^{*}$ \\
\hline \multirow{4}{*}{ 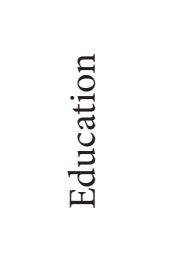 } & Secondary Sch. & $2.69(.67)$ & $2.72(.64)$ & $1.33(.49)$ \\
\hline & High Sch. & $3.40(.69)$ & $3.20(.000)$ & $1.50(.57)$ \\
\hline & Bach./faculty & $2.80(.30)$ & $2.86(.20)$ & $1.16(.12)$ \\
\hline & F/Sig. & $2.25(.109)$ & $.667(.515)$ & $.583(.560)$ \\
\hline
\end{tabular}

${ }^{*} p \leq .05^{* *} p \leq .01$

Starting from the research question how members assess the level of responsibility in relation to various natural and anthropogenic disasters, it was found that most respondents, $62.9 \%$, point out that it is necessary to improve the level of responsibility for responding to fires, while the least emphasis is on responsibility for extreme temperatures. $42.7 \%$ ). The obtained results unequivocally indicate the need to improve the preparedness of these services to respond in such situations (Aleksandrina, Budiarti, Yu, Pasha, \& Shaw, 2019; Cvetkovic, 2019; Kumiko \& Shaw, 2019; Ocal, 2019; Ocal, Cvetković, Baytiyeh, Tedim, \& Zečević, 2020) (Table 4).

Table 4. Perception of the degree of responsibility due to the type of work performed in case of natural and anthropogenic disasters

\begin{tabular}{ccccc}
\hline Opasnosti & \multicolumn{2}{c}{$\mathrm{Da}$} & \multicolumn{3}{c}{$\mathrm{Ne}$} \\
\hline & $\mathrm{N}$ & $\%$ & $\mathrm{~N}$ & $\%$ \\
\cline { 2 - 5 } Fire & 112 & 62.9 & 10 & 5.6 \\
Earthquakes & 92 & 51.7 & 30 & 16.9 \\
Floods & 98 & 55.1 & 20 & 11.2 \\
Extreme temp. & 76 & 42.7 & 44 & 24.7 \\
Terrorist attacks & 84 & 47.2 & 38 & 21.3 \\
\hline
\end{tabular}


In situations where the stability of the functioning of society is disturbed, the efficiency of the response largely depends on the level of individual preparedness. Starting from the research question on the level of individual preparedness, it was determined that members are most ready to react in disasters caused by fires $(M=3.11)$, and least in disasters caused by floods $(\mathrm{M}=2.61)$ (Table 5$)$.

Table 5. Perception of the level of individual preparedness (knowledge, training, plans, etc.) for disasters caused by natural and anthropogenic hazards.

\begin{tabular}{|c|c|c|c|c|c|c|c|c|c|}
\hline \multirow[t]{2}{*}{ Hazards } & \multicolumn{2}{|c|}{ Very unprepared } & \multicolumn{2}{|c|}{ Unprepared (2) } & \multicolumn{2}{|c|}{ Prepared (3) } & \multicolumn{2}{|c|}{ Very prepared(4) } & \multirow{2}{*}{ Mean } \\
\hline & $N$ & $\%$ & $N$ & $\%$ & $N$ & $\%$ & $N$ & $\%$ & \\
\hline Fire & 8 & 4.5 & 14 & 7.9 & 58 & 32.6 & 44 & 35.5 & $3.11(.848)$ \\
\hline Earthquakes & 12 & 6.7 & 32 & 18 & 68 & 38.2 & 12 & 6.7 & $2.65(.788)$ \\
\hline Floods & 14 & 7.9 & 34 & 19.1 & 62 & 34.8 & 14 & 17.9 & $2.61(.833)$ \\
\hline Extreme temp. & 16 & 9 & 30 & 16.9 & 54 & 30.3 & 24 & 13.5 & $2.69(.930)$ \\
\hline Terrorist attacks & 18 & 10.1 & 40 & 22.5 & 48 & 27 & 18 & 10.1 & $2.53(.915)$ \\
\hline
\end{tabular}

In addition to the individual preparedness of members of private security, it is very important to consider the level of readiness of companies that hold private security to respond to such situations. Guided by these reasons, the obtained research results show that companies are the most prepared for fires $(M=3.10)$ and the least prepared for terrorist attacks $(M$ $=2.58)$ (Table 6).

Table 6. Perception of the level of preparedness of a private insurance company for disasters caused by natural and anthropogenic disasters.

\begin{tabular}{|c|c|c|c|c|c|c|c|c|c|}
\hline \multirow[t]{2}{*}{ Hazards } & \multicolumn{2}{|c|}{ Very unprepared } & \multicolumn{2}{|c|}{ Unprepared (2) } & \multicolumn{2}{|c|}{ Prepared (3) } & \multicolumn{2}{|c|}{ Very prepared(4) } & \multirow{2}{*}{ Mean } \\
\hline & $N$ & $\%$ & $N$ & $\%$ & $N$ & $\%$ & $N$ & $\%$ & \\
\hline Fire & 8 & 4.5 & 18 & 10.1 & 48 & 27 & 46 & 25.8 & $3.10(.893)$ \\
\hline Earthquakes & 12 & 6.8 & 28 & 15.6 & 54 & 30.3 & 24 & 13.5 & $2.76(.893)$ \\
\hline Floods & 12 & 6.7 & 28 & 15.7 & 54 & 30.3 & 24 & 13.5 & $2.66(.879)$ \\
\hline Extreme temp. & 14 & 7.9 & 28 & 15.7 & 48 & 27 & 26 & 14.6 & $2.74(.943)$ \\
\hline Terrorist attacks & 20 & 11.2 & 34 & 19.1 & 4 & 22.5 & 24 & 13.5 & $2.58(.999)$ \\
\hline
\end{tabular}

In terms of knowledge of security procedures, they were found to know best fire safety procedures $(M=3.10)$, then earthquakes $(M=2.75)$, floods $(M=2.67)$, extreme temperatures $(\mathrm{M}=2.66)$ and finally terrorist attacks. $(\mathrm{M}=2.52)$ (Table 7$)$. 
Table 7. Knowledge of safety procedures for disaster response caused by natural and anthropogenic disasters.

\begin{tabular}{|c|c|c|c|c|c|c|c|c|c|}
\hline \multirow[t]{2}{*}{ Hazards } & \multicolumn{2}{|c|}{ Not (1) } & \multicolumn{2}{|c|}{ Partially (2) } & \multicolumn{2}{|c|}{ Mostly(3) } & \multicolumn{2}{|c|}{ Yes (4) } & \multirow{2}{*}{ Mean } \\
\hline & $N$ & $\%$ & $N$ & $\%$ & $N$ & $\%$ & $N$ & $\%$ & \\
\hline Fire & / & / & 26 & 14.6 & 58 & 32.6 & 38 & 21.3 & $3.10(.721)$ \\
\hline Earthquakes & 8 & 4.5 & 32 & 18 & 60 & 33.7 & 18 & 10.1 & $2.75(.797)$ \\
\hline Floods & 8 & 4.5 & 36 & 20.2 & 64 & 36 & 12 & 6.7 & $2.67(.748)$ \\
\hline Extreme temp. & 10 & 5.6 & 38 & 21.3 & 52 & 29.2 & 18 & 10.1 & $2.66(.839)$ \\
\hline Terrorist attacks & 14 & 7.9 & 44 & 24.7 & 48 & 27 & 14 & 7.9 & $2.52(.850)$ \\
\hline
\end{tabular}

In addition to security procedures, the effectiveness of first responders' responses was assessed. The highest efficiency scores were rated for firefighters rescuers $(M=3.72)$, followed by military $(M=3.63)$, emergency service $(M=3.38)$ and finally shelves $(M=3.21)$. Thus, according to the obtained results, the efficiency rating is the highest for firefighters rescuers and the lowest for shelves (Table 8).

Table 8. Evaluation of the response efficiency of first responders in natural and anthropogenic disasters.

\begin{tabular}{|c|c|c|c|c|c|c|c|c|c|}
\hline \multirow[t]{2}{*}{ Hazards } & \multicolumn{2}{|c|}{ Very inefficient } & \multicolumn{2}{|c|}{ Inefficient (2) } & \multicolumn{2}{|c|}{ Efficient (3) } & \multicolumn{2}{|c|}{ Very efficient (4) } & \multirow{2}{*}{ Mean } \\
\hline & $N$ & $\%$ & $N$ & $\%$ & $N$ & $\%$ & $N$ & $\%$ & \\
\hline Police & 8 & 4.5 & 12 & 6.7 & 48 & 27 & 54 & 30.3 & $3.21(.874)$ \\
\hline Firefighters rescuers & 2 & 1.1 & 2 & 1.1 & 24 & 13.5 & 92 & 51.7 & $3.72(.582)$ \\
\hline Emergency service & 2 & 1.1 & 12 & 6.7 & 44 & 24.7 & 62 & 34.8 & $3.38(.735)$ \\
\hline Military & 2 & 1.1 & 2 & 1.1 & 34 & 19.1 & 80 & 44.9 & $3.63(.610)$ \\
\hline
\end{tabular}

The question of whether you have received some training for dealing with disasters caused by natural and anthropogenic hazards was answered by 120 respondents (67.4\%). Out of the total number, $66(37.1 \%)$ respondents answered that they had completed certain training, while $52(29.2 \%)$ respondents answered that they had not completed such training. In relation to the total number of respondents who did not complete the mentioned training, the reasons for non-attendance are the following: I do not have time - $22(12.4 \%)$, I do not have money - $26(38.2 \%)$, I think it does not matter - 2 (1.1\%), does not think about it - $6(3.4 \%)$, information is not available to him $-8(4.5 \%)$, etc.

\section{Conclusions}

Members of the private security are mostly accustomed to facing threats that come primarily from people, and that is why the level of their preparedness to react to disasters caused by natural or anthropogenic influences remains at a very low level. On the other hand, the increase in the number and severity of disaster consequences simply imposes the need for further training and training to respond to disaster-induced conditions. The obtained research results clearly indicate the urgent need to design appropriate strategies and programs within which to design better education and training of members of private security. A very low level of training attendance was identified, which would enable members to better pre- 
pare so that the level of response efficiency would be at a much higher level. The limitations of the conducted research are reflected in the insufficient number of respondents covered by the research as well as the insufficient representation of various private security agencies. In further research, it is necessary to look even more deeply and comprehensively at all the needs and possibilities of members of private security for a more efficient way of reacting in given situations.

Author Contributions: V.M.C. had the original idea for this study and developed the study design and questionnaire with B.J. contributed to questionnaire dissemination, while V.M.C. analyzed and interpreted the data. B.J. made special contribution by drafting the introduction; B.J. and V.M.C. have drafted the discussion and E.N. the conclusions. V.M.C., critically reviewed the data analysis and contributed to the content for revising and finalizing the manuscript.

Funding: This research was funded by Scientific-Professional Society for Disaster Risk Management (http://upravljanje-rizicima.com/), Belgrade, Serbia, 004/2020.

Conflicts of Interest: Declare conflicts of interest or state "The authors declare no conflict of interest."

\section{References}

1. Aleksandrina, M., Budiarti, D., Yu, Z., Pasha, F., \& Shaw, R. (2019). Governmental Incentivization for SMEs' Engagement in Disaster Resilience in Southeast Asia. International Journal of Disaster Risk Management, 1(1), 32-50.

2. Brito, C. S., Luna, A. M., \& Sanberg, E. L. (2009). Benchmarks for developing a law enforcement pandemic flu plan. Washington, D.C: Police Executive Research Forum.

3. Cobbina, J. E., Nalla, M. K., \& Bender, K. A. (2013). Security officers' attitudes towards training and their work environment. Security Journal, 29(3), 385-399. doi:10.1057/sj.2013.34

4. Cvetkovic, V. M. (2019). Risk Perception of Building Fires in Belgrade. International Journal of Disaster Risk Management, 1(1), 81-91.

5. Cvetković, V., Nikolić, N., Nenadić, R. U., Ocal, A., \& Zečević, M. (2020). Preparedness and Preventive Behaviors for a Pandemic Disaster Caused by COVID-19 in Serbia. International Journal of Environmental Research and Public Health, 17(11), 4124.

6. Davidović, D., \& Kešetović, Ž. (2017). Privatni polising i risk menadžment u Srbiji [Private policing and risk management in Serbia]. Kriminalističke teme(5), 186-198.

7. Đorđević, S. (2020). Policija u vreme vanrednog stanja [Police during a state of emergency]. Beograd: Beogradski centar za bezbednosnu politiku

8. Janković, B. (2020). The Role of Stewards at Sports Events in the Republic of Serbia. Zbornik radova Pravnog fakulteta Novi Sad, 54(1), 353-365. doi:10.5937/zrpfns54-23518

9. Janković, B., Cvetković, V. M., \& Ivanov, A. (2019). Perceptions of private security: a case of students from Serbia and North Macedonia. NBP - Journal of Criminalistics and Law, 24(3), 59-72. doi:10.5937/nabepo24-23302

10. Kumiko, F., \& Shaw, R. (2019). Preparing International Joint Project: Use of Japanese Flood Hazard Map in Bangladesh. International Journal of Disaster Risk Management, $1(1), 62-80$.

11. Lončar, Z. J., Radivojević, N. P., Radošević, R. S., \& Mirković, V. M. (2019a). Saradnja policije i privatnog obezbeđenja u vanrednim situacijama u Republici Srbiji - stanje i 
mogućnosti. Zbornik radova Pravnog fakulteta, Novi Sad, 53(1), 113-131. doi:10.5937/ zrpfns53-22005

12. Lončar, Z. J., Radivojević, N. P., Radošević, R. S., \& Mirković, V. M. (2019b). Saradnja policije i privatnog obezbeđenja u vanrednim situacijama u Republici Srbiji - stanje i mogućnosti - [Cooperation between Police and Private Security in Emergency Situations in the Republic of Serbia - Current State and Possibilities]. Zbornik radova Pravnog fakulteta, Novi Sad, 53(1), 113-131. doi:10.5937/zrpfns53-22005

13. Luna, A. M., Brito, C. S., \& Sanberg, E. A. (2007). Police Planning for an Influenza Pandemic: Case Studies and Recommendations from the Field. Washington, DC: Police Executive Research Forum.

14. Milojković, B., Milojević, S., Vučković, G., Janković, B., Gligorijević, M., \& Jokić, N. (2015). Certain aspects of provoding use of police units in actions of protection and rescuing in case of natural disasters. In Archibald reiss days (pp. 407-422). Belgrade: The Academy of Criminalistic and Police Studies, Belgrade.

15. Milošević, M. D. (2018). Privatizacija bezbednosti u postkonfliktnim državama: slučaj Srbije i Hrvatske 2000-2016. godine [Privatization of security in post-conflict countries: The case of Serbia and Croatia in the period 2000 - 2016]. (doktorska disertacija), Beograd, Beograd.

16. Montgomery, D. C., Peck, E. A., \& Vining, G. G. (2012). Introduction to linear regression analysis (Vol. 821): John Wiley \& Sons.

17. Nalla, M. K., \& Cobbina, J. E. (2017). Environmental factors and job satisfaction: The case of private security guards. Security Journal, 30(1), 215-226. doi:10.1057/sj.2016.12

18. Nalla, M. K., \& Crichlow, V. J. (2017). Have the standards for private security guards become more stringent in the post 9/11 era? An assessment of security guard regulations in the US from 1982 to 2010. Security Journal, 30(2), 523-537. doi:10.1057/sj.2014.21

19. Nalla, M. K., \& Gurinskaya, A. (2017). Common past - different paths: Exploring state regulation of private security industry in Eastern Europe and post-Soviet republics. International Journal of Comparative and Applied Criminal Justice, 41(4), 305-321. doi:10 $.1080 / 01924036.2017 .1368921$

20. Ocal, A. (2019). Natural Disasters in Turkey: Social and Economic Perspective. International Journal of Disaster Risk Management, 1(1), 51-61.

21. Ocal, A., Cvetković, V. M., Baytiyeh, H., Tedim, F., \& Zečević, M. (2020). Public reactions to the disaster COVID-19: A comparative study in Italy, Lebanon, Portugal, and Serbia. Geomatics, Natural Hazards and Risk. doi:10.1080/19475705.2020.1811405

22. Steden, R. v. (2007). Privatizing policing: Describing and explaining the growth of private security. Amsterdam: Vrije Universiteit Amsterdam.

23. Xuesong, G., \& Kapucu, N. (2019). Examining Stakeholder Participation in Social Stability Risk Assessment for Mega Projects using Network Analysis. International Journal of Disaster Risk Management, 1(1), 1-31.

24. Zakon o privatnom obezbeđenju, (2013).

25. Zakon o smanjenju rizika od katastrofa i upravljanju vanrednim situacijama, (2018). 
